\title{
Karin Becker, Villons «Testament» - ein Totentanz?
}

\section{G. Matteo Roccati}

\section{(2) OpenEdition}

\section{Journals}

Édition électronique

URL : http://journals.openedition.org/studifrancesi/5878

DOI : 10.4000/studifrancesi.5878

ISSN : 2427-5856

\section{Éditeur}

Rosenberg \& Sellier

\section{Édition imprimée}

Date de publication : 1 mai 2011

Pagination : 149

ISSN : 0039-2944

\section{Référence électronique}

G. Matteo Roccati, « Karin Becker, Villons «Testament» - ein Totentanz?», Studi Francesi [En ligne], 163 (LV | I) | 2011, mis en ligne le 30 novembre 2015, consulté le 13 janvier 2021. URL : http:// journals.openedition.org/studifrancesi/5878; DOI : https://doi.org/10.4000/studifrancesi.5878

Ce document a été généré automatiquement le 13 janvier 2021.

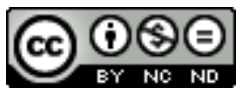

Studi Francesi è distribuita con Licenza Creative Commons Attribuzione - Non commerciale - Non opere derivate 4.0 Internazionale. 


\title{
Karin Becker, Villons «Testament»- ein Totentanz?
}

\author{
G. Matteo Roccati
}

\section{RÉFÉRENCE}

KARIN BECKER, Villons «Testament» - ein Totentanz?, in L'art macabre 11, Jahrbuch der Europäischen Totentanz-Vereinigung, Association Danses Macabres d'Europe, Bundesrepublik Deutschland e.V., heraussgegeben von Uli wUNDERLICH, Bamberg, 2010, pp. 33-56.

1 L'article souligne la parenté du texte avec l'ordonnancement même de la danse macabre et relève les traits qui l'apparentent à cette dernière ainsi qu'au genre de l'ars moriendi: rappels de la mort et recours insistant au thème du memento mori, thème de la mors intravitalis (péché et vanité du monde), procédés énumératifs, descriptions physiques, etc. Ces traits sont analysés dans quelques passages où ils sont particulièrement évidents. Villon, tout en s'inspirant du modèle du cimetière des Saints Innocents, renouvelle le thème et lui insuffle une nouvelle intensité. Dans sa conclusion il le subvertit cependant de manière «carnavalesque», par la parodie et l'ironie, et cet aspect est encore accentué dans un des manuscrits $(C)$ par les deux ballades qui terminent le Testament (Epistre à ses amis et Ballade de Fortune). 